\title{
Increased Sulfation of Glycoconjugates by Cultured Nasal Epithelial Cells from Patients with Cystic Fibrosis
}

\author{
Pi-Wan Cheng, ${ }^{\star \neq}$ Thomas F. Boat,“ Karen Cranfill,“ James R. Yankaskas, ${ }^{5}$ and Richard C. Boucher \\ Departments of ${ }^{*}$ Pediatrics, ${ }^{\ddagger}$ Biochemistry, and ${ }^{\S}$ Medicine, University of North Carolina, Chapel Hill, North Carolina $27599-7220$
}

\begin{abstract}
Cystic fibrosis (CF) respiratory epithelia exhibit abnormal anion transport that may be linked to abnormal lung defense. In these studies, we investigated whether primary cultures of CF respiratory epithelial cells regulate abnormally the sulfate content of high molecular weight glycoconjugates (HMG) participating in airways' mucosal defense. HMG, including glycosaminoglycans and mucin-type glycoproteins released spontaneously into medium and HMG released from cell surfaces by trypsin, were metabolically labeled with ${ }^{35} \mathrm{SO}_{4}{ }^{2}$ and $\left[6-{ }^{3} \mathrm{H}\right]-$ glucosamine (GlcN) or ${ }^{35} \mathrm{SO}_{4}{ }^{2}$ and $\left[{ }^{3} \mathrm{H}\right]$ serine. All three classes of HMG from CF cells exhibited ${ }^{35} \mathrm{~S} /{ }^{3} \mathrm{H}$ labeling ratios 1.5-4fold greater than HMG from normal or disease control cells. Differences for labeling ratios of HMG from CF cells were shown to be the consequence of increased ${ }^{35} \mathrm{SO}_{4}{ }$ incorporation rather than decreased peptide synthesis and release or HMG glycosylation. The buoyant density of CF mucin-type HMG also was increased, consistent with increased sulfation. These observations suggest that oversulfation of a spectrum of HMG is a genetically determined characteristic of CF epithelial cells and may play an important pathophysiological role by altering the properties of mucous secretions and/or the interactions between selected bacteria and HMG at the airways' surface.
\end{abstract}

\section{Introduction}

Cystic fibrosis $(C F)^{1}$ is a genetic disease characterized by abnormal epithelial electrolyte transport. Failure to secrete $\mathrm{Cl}^{-}$ and excessive reabsorption of $\mathrm{Na}^{+}$in the large airways' epithelium of CF patients (1-6) could lead to dehydration and accumulation of secretions. However, these abnormalities alone are unlikely to explain the progressive course of airway obstruction and persistent infection with specific microorganisms such as Staphylococcus aureus and Pseudomonas aeruginosa, because failure to clear secretions secondary to dysmotile cilia (7) generally is associated with less severe airway disease.

Address reprint requests to Dr. Pi-Wan Cheng, Department of Pediatrics, 635 Clinical Sciences Bldg., CB 7220, University of North Carolina at Chapel Hill, Chapel Hill, NC 27599-7220.

Received for publication 15 November 1988 and in revised form 4 January 1989.

1. Abbreviations used in this paper: $\mathrm{CF}$, cystic fibrosis; DC, disease control; GlcN, glucosamine; HMG, high molecular weight glycoconjugates; PAPS, 3'-phosphoadenosine 5'-phosphosulfate.

J. Clin. Invest.

(c) The American Society for Clinical Investigation, Inc. 0021-9738/89/07/0068/05 \$2.00

Volume 84, July 1989, 68-72
Previous studies showed that high molecular weight glycoconjugates (HMG) secreted by CF airways in situ (8) and in organ culture $(9,10)$ are oversulfated. However, it has not been clear whether this is an acquired abnormality (11) or whether it is related to the basic defect in CF. Recently, Yankaskas et al. (12) demonstrated that CF nasal epithelial cells in primary culture retain epithelial cell polarity and the electrolyte transport properties that distinguish $\mathrm{CF}$ from normal or disease control (DC) subjects. We have demonstrated that these cultured cells produce and release sulfated HMG (13). We now report that the HMG synthesized by cultured CF nasal epithelial cells are more highly sulfated as compared with the HMG produced by normal or DC cells.

\section{Methods}

Human tissues. Nasal polyps and turbinates surgically removed from patients with allergic rhinitis (DC) or no known inflammatory process in the upper airway (normal) were used for these studies. CF patients had elevated levels of sweat chloride, typical pulmonary disease, and pancreatic insufficiency. DC patients had seasonal rhinitis and eosinophilia. Normal patients had obstructive sleep apnea or anatomic airway narrowing but no atopic symptoms (6). Details concerning tissue donors are included in figure legends. Tissues were rinsed in normal saline and transported to the laboratory in MEM at $4^{\circ} \mathrm{C}$ by ground (local hospitals) or overnight air (distant hospitals) carrier.

Culture conditions. The epithelial cells were dissociated from freshly excised nasal tissues by incubation in $0.1 \%$ protease (Type XIV, Sigma Chemical Co.) for $16 \mathrm{~h}$ and cultured on collagen matrices in Ham's F-12 medium supplemented with hormones as described (12). When cultured cells reached confluence, the media were changed to a 1:1 mixture of hormone-supplemented F-12 medium and DME conditioned by 3T3 fibroblasts for $4 \mathrm{~d}$. All confluent cultures showed transepithelial electric potentials characteristic of CF and non-CF cells as previously noted (12).

Radiolabeling of newly synthesized HMG. HMG synthesized by the cultured cells were labeled with radioisotope precursors, $\left[6-{ }^{3} \mathrm{H}\right]-$ GlcN (25-40 Ci/mmol) $(20 \mu \mathrm{Ci} / \mathrm{ml})$ and carrier-free $\mathrm{Na}_{2}{ }^{35} \mathrm{SO}_{4}(100$ $\mu \mathrm{Ci} / \mathrm{ml})$, or $\left[{ }^{3} \mathrm{H}\right]$ serine $(7-8 \mathrm{Ci} / \mathrm{mmol})(40 \mu \mathrm{Ci} / \mathrm{ml})$ and $\mathrm{Na}^{35} \mathrm{SO}_{4}(100$ $\mu \mathrm{Ci} / \mathrm{ml}$ ), added to either the apical or basolateral medium. Except where indicated, media were harvested daily and replaced with fresh media. Because steady state secretion of radiolabeled HMG is reached during the second day of culture (13), the apical media on days 2-4 were combined. HMG were isolated on Sepharose CL-6B (Pharmacia Fine Chemicals, Piscataway, NJ) (14) and quantitated by liquid scintillation counting. In all experiments, pairs of $\mathrm{CF}$ and normal cells or normal and DC cells were handled identically and studied in parallel.

Trypsin treatment of cultured cells. Cultured cells were exposed to porcine pancreatic trypsin $(300 \mathrm{U} / \mathrm{ml}$ medium) added to the apical compartment for $30 \mathrm{~min}$. Soybean trypsin inhibitor was then introduced at a final concentration of $200 \mu \mathrm{g} / \mathrm{ml}$, before isolation and quantitation of HMG as described above. Cultured cells exposed to trypsin or medium alone were fixed in $2 \%$ formaldehyde $2 \%$ glutaraldehyde at $4^{\circ} \mathrm{C}$ overnight before Epon embedding for electron microscopy.

Other methods. Amino acid composition of HMG was determined by an HPLC procedure modified from that of Bidlinmeyer et al. (15). 
Modifications include addition of $200 \mathrm{mM}$ boric acid to the acetate buffer and the utilization of an internal standard, 6-amino- $n$-hexanoic acid, which is eluted $1-2$ min before tyrosine. $\mathrm{CsCl}$ density gradient centrifugation was performed at a starting density of $1.55 \mathrm{~g} / \mathrm{ml}$ in a rotor (type 65; Beckman Instruments, Fullerton, CA) at $10^{\circ} \mathrm{C}$ and $150,000 \mathrm{~g}$ for $35-45 \mathrm{~h}$. Fractions were collected by a pump (DensiFlow Haake Buchler Instruments, Inc., Saddle Brook, NJ). The density of each fraction was calculated from the refractive index and radioactivity was measured by a liquid scintillation counter. Treatment with bovine testicular hyaluronidase $(400 \mathrm{U} / \mathrm{ml}$, Sigma Chemical Co.) was performed in $50 \mathrm{mM}$ sodium acetate, $\mathrm{pH} 5.0$, containing $2 \mathrm{mM}$ PMSF at $37^{\circ}$ for $4 \mathrm{~h} \mathrm{(16).}$

Statistical Analyses. Data are expressed as means \pm SEM. Differences between means for each study group were analyzed by nonpaired $t$ test.

\section{Results}

Oversulfation of HMG spontaneously released by $C F$ cells. Several lines of evidence suggest that radiolabeled HMG released by cultured CF cells are excessively sulfated. First, normalizing ${ }^{35} \mathrm{SO}_{4}{ }^{2}$ incorporation to carbohydrate content as determined by $\left[{ }^{3} \mathrm{H}\right] \mathrm{GlcN}$ incorporation, we found that the mean ${ }^{35} \mathrm{~S} /{ }^{3} \mathrm{H}(\mathrm{GlcN})$ ratio of total $\mathrm{HMG}$ released by cultured cells into the apical bathing media was twofold higher for $\mathrm{CF}$ than for normal or DC cells (Table I). ${ }^{35} \mathrm{~S} /{ }^{3} \mathrm{H}(\mathrm{GlcN})$ ratios for $\mathrm{HMG}$ released by normal and DC cells were not different. The abnormally higher ratio is due to increased ${ }^{35} \mathrm{~S}$ label associated with HMG and not underglycosylation because the release rate of ${ }^{35} \mathrm{~S}$ label associated with $\mathrm{HMG}\left(\mathrm{dpm} / \mathrm{mm}^{2}\right.$ surface area) during a 24 -h period by CF cells $\left(1.98 \pm 0.32 \times 10^{3}\right)(n=21$ collagen matrices from 11 donors) was greater than that of normal cells $\left(1.16 \pm 0.21 \times 10^{3}\right)(n=20$ collagen matrices from 10 donors $)(P<0.05)$ whereas the rate of release of ${ }^{3} \mathrm{H}$ label associated with HMG was not different for CF $(8.94 \pm 1.69$ $\left.\times 10^{3}\right)(n=21)$ and normal cells $\left(9.82 \pm 1.82 \times 10^{3}\right)(n=20)(P$ $>0.5)$. Second, when $\left[{ }^{3} \mathrm{H}\right] \mathrm{GlcN}$ was replaced with $\left[{ }^{3} \mathrm{H}\right] \mathrm{Ser}$ in double-labeling experiments to normalize sulfate to peptide content, the ${ }^{35} \mathrm{~S} /{ }^{3} \mathrm{H}(\mathrm{Ser})$ ratio for the HMG released by $\mathrm{CF}$ cells was threefold higher than that of the HMG released by normal and DC cells (Table II). Again, no difference was detected for ${ }^{35} \mathrm{~S} /{ }^{3} \mathrm{H}(\mathrm{Ser})$ ratios of $\mathrm{HMG}$ released from normal and DC cells. We further verified that the rate of release of HMG expressed as peptide content ( $\mu \mathrm{g} / \mathrm{d}-\mathrm{cm}^{2}$ surface area),

Table I. ${ }^{35} \mathrm{~S} /{ }^{3} \mathrm{H}(\mathrm{GlcN})$ Ratios for HMG Released into Apical Medium under Basal Culture Conditions*

\begin{tabular}{lccc}
\hline \multicolumn{1}{c}{ Cells } & No. subjects & ${ }^{35} \mathrm{~S} /{ }^{3} \mathrm{H}(\mathrm{GlcN})$ ratios & $P$ \\
\hline \multicolumn{4}{c}{ Mean \pm SEM } \\
Normal (N) & 21 & $0.14 \pm 0.01$ & $<0.001$ (N vs. CF) \\
CF & 12 & $0.28 \pm 0.03$ & $<0.005$ (CF vs. DC) \\
DC & 13 & $0.15 \pm 0.05$ &
\end{tabular}

\footnotetext{
* The diameter of collagen matrices was 3-5 mm. Labeling ratios did not differ when precursors were added to the apical $(0.6 \mathrm{ml})$ or basolateral $(1.0 \mathrm{ml})$ compartments. Greater than $88 \%$ of the radiolabeled HMG released by cultured cells were recovered in the apical media. ‡ The gender and age of tissue donors are: normal, 12 males, 9 females, age range, 15-68, mean age, 33; CF, 4 males, 8 females, age range, 6-20, mean age, 14; and DC, 4 males, 9 females, age range, $7-45$, mean age, $28 .{ }^{35} \mathrm{~S} /{ }^{3} \mathrm{H}(\mathrm{GlcN})$ ratios for normal, $\mathrm{CF}$, or DC groups did not change with sex or age.
}

Table II. ${ }^{35} \mathrm{~S} /{ }^{3} \mathrm{H}(\mathrm{Ser})$ Ratios for HMG Released into Apical Media under Basal Culture Conditions*

\begin{tabular}{lccc}
\hline Cells & No. subjects $^{\ddagger}$ & ${ }^{35} \mathrm{~S} /{ }^{3} \mathrm{H}(\mathrm{Ser})$ ratios & $P$ \\
\hline & & Mean $\pm S E M$ & \\
Normal & 6 & $0.29 \pm 0.05$ & $<0.001$ (N vs. CF) \\
CF & 6 & $0.71 \pm 0.06$ & $<0.001$ (DC vs. CF) \\
DC & 3 & $0.20 \pm 0.04$ &
\end{tabular}

\begin{abstract}
* The diameter of collagen matrices was $30 \mathrm{~mm}$. Radiolabelled precursors were added to the basolateral medium $(0.5 \mathrm{ml})$. Volume of the apical compartment was $4 \mathrm{ml}$.

₹ The gender and age of nasal tissue donors were: normal, three males, three females, age range, 5-40, mean age, 25 ; CF, three males, three females, age range, 6-30, mean age, 18; and DC, one male, two females, age range, 23-62, mean age, 39. No apparent sex- or age-related change in ${ }^{35} \mathrm{~S} /{ }^{3} \mathrm{H}$ (ser) ratio was observed for any of these three groups.
\end{abstract}

measured by amino acid analysis, was not different for cells from these three sources: normal, $8.3 \pm 1.7(n=6)$; CF, 7.1 \pm 0.8 $(n=6)$; and DC, $7.9 \pm 0.3(n=3)$.

HMG released into media by cultured cells contain several classes of glycoconjugates (13). Therefore, we examined whether oversulfation of HMG is a general phenomenon or is limited to a specific class of HMG. When HMG isolated from apical media were treated with bovine testicular hyaluronidase, $49 \%$ of the ${ }^{3} \mathrm{H}(\mathrm{GlcN})$-label and $35 \%$ of the ${ }^{35} \mathrm{~S}$ label were liberated from HMG, suggesting that glycosaminoglycans such as chondroitin sulfates, dermatan sulfate, and hyaluronic acid are released into the medium (16). The mean ${ }^{35} \mathrm{~S} /{ }^{3} \mathrm{H}(\mathrm{GlcN})$ ratio for hyaluronidase-susceptible HMG (glycosaminoglycans) released by $C F$ cells $(0.21 \pm 0.05)(n=12)$ was 3.5 times that for glycosaminoglycans from normal cells $(0.06 \pm 0.01)$ ( $n$ $=21)(P<0.001)$. Similarly, the mean ${ }^{35} \mathrm{~S} /{ }^{3} \mathrm{H}(\mathrm{GlcN})$ ratio of hyaluronidase-resistant HMG from CF cells $(0.26 \pm 0.02)$ ( $n$ $=12)$ was $50 \%$ higher than that from normal cells $(0.17 \pm 0.01)$ $(n=21)(P<0.001)$. Approximately $40 \%$ of $N$-acetylgalactosamine in hyaluronidase-resistant HMG was converted to $N$ acetylgalactosaminitol after alkaline borohydride treatment (17), suggesting that these HMG contain mucin-type carbohydrate to peptide linkages. The mucin-type HMG from CF cells were more heterogeneous than control HMG with respect to density (Fig. 1, $A$ and $B$ ). The peak buoyant density of hyaluronidase-resistant HMG released by normal cells was 1.52 and $1.53 \mathrm{~g} / \mathrm{ml}$ for ${ }^{3} \mathrm{H}$ label and ${ }^{35} \mathrm{~S}$ label, respectively (Fig. $1 \mathrm{~A}$ ). The peak buoyant density of hyaluronidase-resistant HMG released by CF cells was 1.55 and $1.59 \mathrm{~g} / \mathrm{ml}$ for ${ }^{3} \mathrm{H}$ label and ${ }^{35} \mathrm{~S}$ label, respectively (Fig. $1 \mathrm{~B}$ ). Because sulfate is more dense than either carbohydrates (18) or amino acids (19), these results are consistent with increased sulfation of CF mucintype HMG.

Increased sulfation of cell surface HMG. Oversulfation was not limited to CF HMG spontaneously released into the medium. CF HMG released from the cell surface by trypsin had a ${ }^{35} \mathrm{~S} /{ }^{3} \mathrm{H}$ (Ser) ratio $3-4$-fold greater than that of normal or disease control HMG (Table III). Electron microscopy of the apical membranes of cultured cells treated with trypsin showed substantial loss of glycocalyx over tips of microvilli (Fig. 2), suggesting that the HMG released by trypsin are at least in part associated with the apical cell surface. 

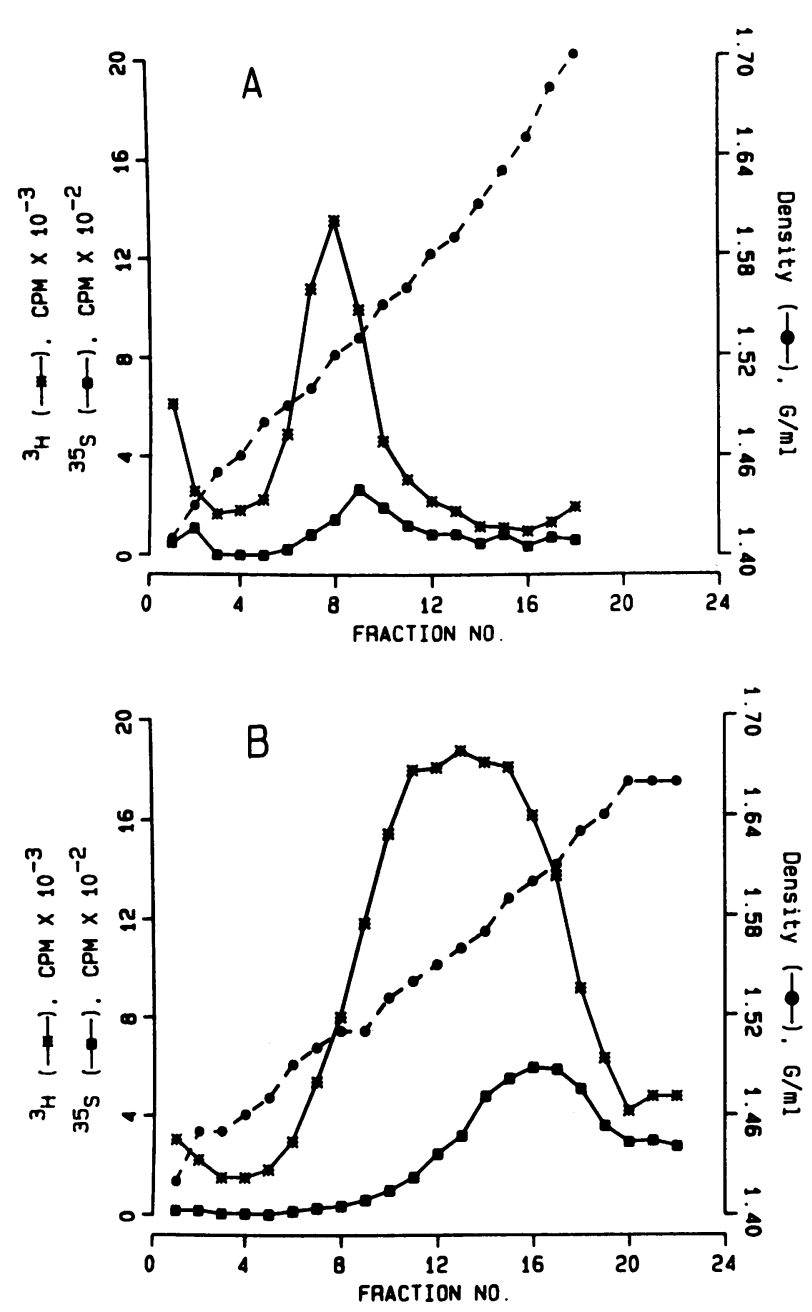

Figure 1. $\mathrm{CsCl}$ density gradient centrifugation profiles of hyaluronidase-resistant HMG isolated from combined apical media of cultured normal $(A)$ and $C F(B)$ cells. These glycoconjugates were centrifuged at a starting density of $1.55 \mathrm{~g} / \mathrm{ml}$.

\section{Discussion}

Synthesis of HMG peptides takes place at the rough endoplasmic reticulum using mRNAs as templates although glycosylation of newly synthesized peptides occurs in the Golgi apparatus in a step-wise manner catalyzed by a variety of glycosyltransferases. Oligosaccharides are then sulfated when their assembly in the Golgi is near completion. Radiolabeled precursors, $\left[{ }^{3} \mathrm{H}\right] \operatorname{ser},\left[{ }^{3} \mathrm{H}\right] \mathrm{GlcN}$, and ${ }^{35} \mathrm{SO}_{4}{ }^{2}$ used in this study serve

Table III. ${ }^{35} \mathrm{~S} /{ }^{3} \mathrm{H}(\mathrm{Ser})$ Ratios for HMG Released by Trypsin*

\begin{tabular}{lccc}
\hline Cells & No. subjects & ${ }^{35} \mathrm{~S} /{ }^{3} \mathrm{H}(\mathrm{Ser})$ ratios & $P$ \\
\hline & & Mean \pm SEM & \\
Normal & 6 & $0.28 \pm 0.09$ & $<0.005$ (N vs. CF) \\
CF & 6 & $0.85 \pm 0.12$ & $<0.01$ (DC vs. CF) \\
DC & 3 & $0.20 \pm 0.04$ &
\end{tabular}

* After media were harvested on day 4, the cultured cells were exposed to porcine pancreatic trypsin as described in the text. Tissue donors and culture conditions are described in Table II. as indices of peptide, carbohydrate, and sulfate contents, respectively. The higher ${ }^{35} \mathrm{~S} /{ }^{3} \mathrm{H}$ (GlcN or ser) ratios for CF HMG as compared to non-CF HMG indicate that sulfation relative to glycosylation or peptide synthesis is increased in CF cells. Because rates of release of ${ }^{3} \mathrm{H}(\mathrm{GlcN})$-label associated with HMG and HMG peptide measured chemically are not different statistically between CF and non-CF cells while rate of release of ${ }^{35} \mathrm{SO}_{4}$-label associated with HMG is significantly higher in $\mathrm{CF}$ as compared with non-CF cells, we conclude that CF HMG are more heavily sulfated than non-CF HMG. Higher buoyant density exhibited by CF mucin-type HMG is consistent with this conclusion.

Previous studies demonstrating increased sulfation of HMG secreted by CF airways in situ (8) or in organ culture (9, 10 ) have been interpreted by some to reflect an acquired abnormality, perhaps related to intensity of chronic airway inflammation (11). However, our studies show that increased sulfation of CF HMG persists during primary culture of nasal epithelial cells, whereas HMG synthesized by DC nasal epithelial cells in culture are not oversulfated as compared with normal controls. Therefore, oversulfation of CF HMG can not be attributed to the effects of chronic airways inflammation. We propose that increased sulfation of HMG is closely related to the fundamental biochemical abnormality in CF epithelial cells. Our observation that glycosaminoglycans as well as mucin-type HMG released spontaneously from cultured cells and cell surface HMG are oversulfated suggest that the CF sulfation abnormality affects many or all sulfated respiratory epithelial macromolecules.

Cellular events that potentially modulate the sulfation of HMG are illustrated in Fig. $3 A$. These include (a) translocation of sulfate ions across the plasma membrane by exchange or conductive pathways identified in human skin fibroblasts (20) and toad skin (21), respectively; (b) intracellular generation of sulfate from sulfur-containing amino acids (22); (c) formation of 3'-phosphoadenosine 5'-phosphosulfate (PAPS) from inorganic sulfate (22); and $(d)$ transport of PAPS across the Golgi membrane to provide the sulfate donor for the synthesis of sulfated macromolecules in the Golgi apparatus (23). Current evidence suggests that sulfate metabolism exclusive of transport is similar across species and tissue lines. If, as is likely, the pool size or turn-over rate of $\mathrm{SO}_{4}{ }^{2}$ is rate limiting for HMG sulfation, the oversulfation of HMG by CF epithelial cells does not necessarily add to the complexity of the fundamental cellular dysfunction. For example, as shown in Fig. 3 $B$, several previously described abnormalities of CF epithelial cell ion transport or metabolic pathways could perturb the kinetics of the $\mathrm{SO}_{4}{ }^{-}$pool: $(a)$ abnormal regulation (1-5) of a putative cellular $\mathrm{SO}_{4}{ }^{2}$ transporter (20); $(b)$ increased ATP supplies (24); and/or (c) alteration of a functional anion conductance that would limit the efflux of intracellular $\mathrm{SO}_{4}{ }^{-}(21)$.

Current evidence suggests that $\mathrm{CF}$ epithelial cell dysfunction, particularly abnormal $\mathrm{Cl}^{-}$(and perhaps $\mathrm{Na}^{+}$) translocation across the apical membrane, can be traced to a malfunctioning regulatory step downstream from the regulatory kinases (1-6). A projected consequence of this ion transport dysfunction is a failure to provide water in adequate amounts for hydration of airways surface liquids, which may alter the viscoelastic properties of mucous gels $(25,26)$. Increased sulfation of HMG also may contribute to altered physical properties of mucus (27). However, as indicated above, reduced mucus clearance alone can not adequately explain coloniza- 

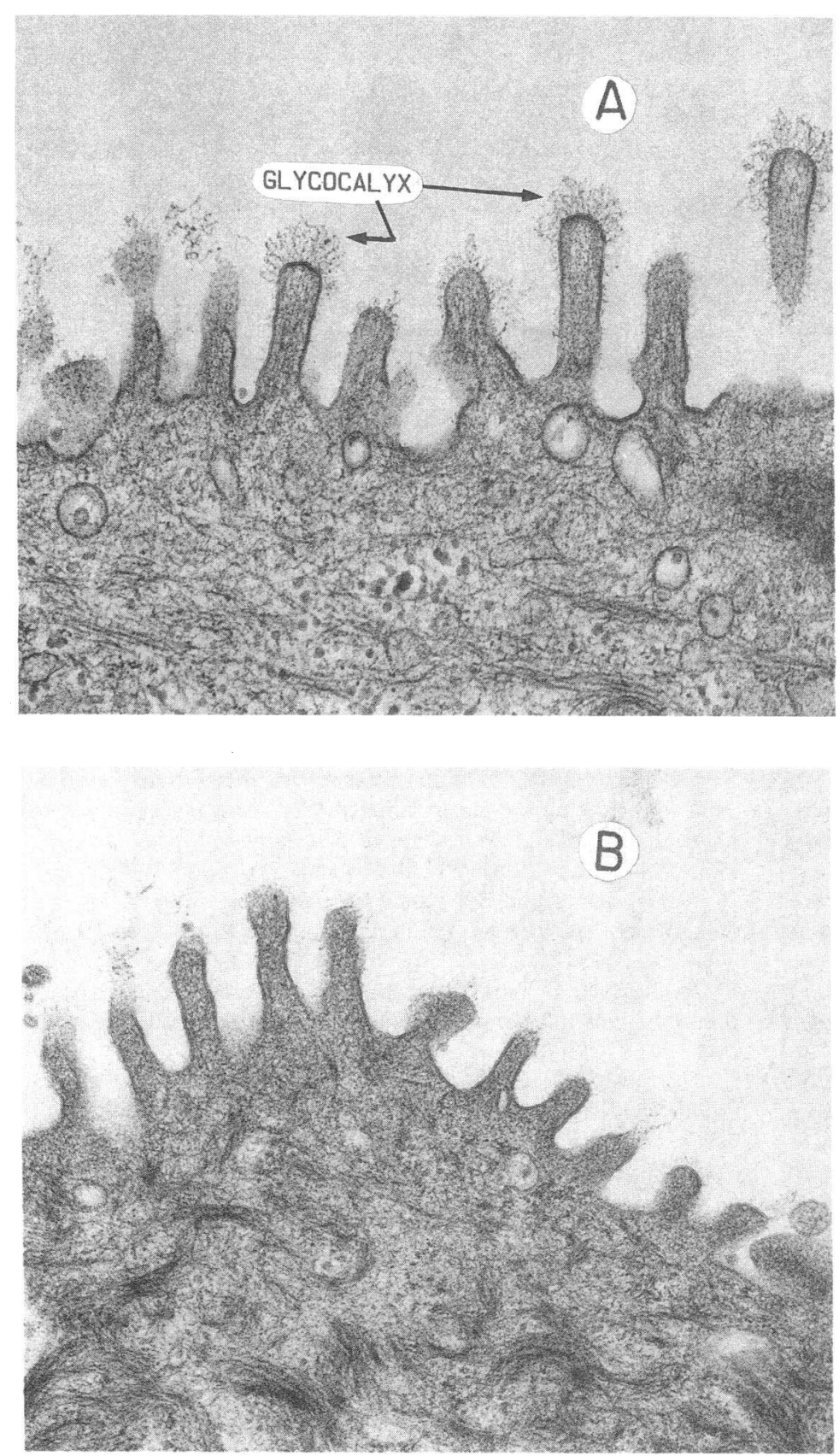

Figure 2. Electron micrographs $(\times 50,000)$ of the apical surface of cultured human nasal epithelial cells without $(A)$ and with $(B)$ trypsin treatment.
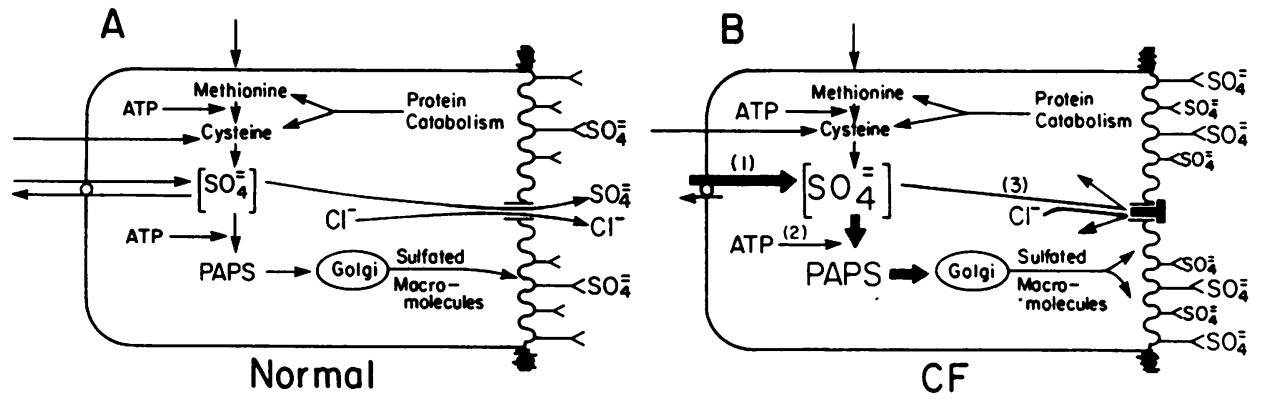

Figure 3. Proposed sulfate transport and metabolism schemes in normal $(A)$ and $\mathrm{CF}(B)$ respiratory epithelial cells. Tight junctions are shown as the extra cellular shaded areas; (right) epithelial cell apical surface, (left) basolateral surface. Anion channels are depicted by parallel lines interrupting apical membranes. Sulfate exchange transport pathway is depicted by arrow-connected circle and arbi-

trarily depicted on the basolateral membrane. Glycocalyxceal macromolecules are depicted by branched figures on the apical cell surface. Numbers in $B$ correspond to steps potentially perturbed in CF cells: (1), anion exchange; (2), ATP-dependent sulfate activation; (3), anion conductance. 
tion of CF airways by selective microbial pathogens. For example, patients with other genetic diseases that lack mucociliary clearance generally are not infected with these microorganisms and do not usually succumb to lung disease in the first two to three decades of life (7). We speculate that oversulfated epithelial HMG provide a clue to the selection of $P$. aeruginos $a$ and $S$. aureus in CF airways by $(a)$ providing a favored site for binding of these bacteria $(28,29)$ at epithelial cell surfaces and/or $(b)$ adversely influencing the interaction between HMG components of airways secretions and specific microorganisms (8).

\section{Acknowledgments}

The authors thank the many CF patients and control subjects and their physicians and nurses, who provided tissues for this study, and Grace Chen, Kim Baker, Jayne Goodman, and Jan Davis for expert technical assistance.

This work was supported by grants from the National Institutes of Health (HL-34322) and the Cystic Fibrosis Foundation.

\section{References}

1. Welsh, M. J., and C. M. Liedtke. 1986. Chloride and potassium channels in cystic fibrosis airway epithelia. Nature (Lond.). 322:467470.

2. Frizzell, R. A., G. Rechkemmer, and R. L. Shoemaker. 1986. Altered regulation of airway epithelial cell chloride channels in cystic fibrosis. Science (Wash. DC). 233:558-560.

3. Barthelson, R., and J. J. Widdicombe. 1987. Cyclic adenosine monophosphate-dependent kinase in cystic fibrosis tracheal epithelium. J. Clin. Invest. 80:1799-1802.

4. Schoumacher, R. A., R. L. Shoemaker, D. R. Halm, E. A. Tallant, R. A. Wallace, and R. A. Frizzell. 1987. Phosphorylation fails to activate chloride channels from cystic fibrosis airway cells. Nature (Lond.). 330:752-754.

5. Li, M., J. D. McCann, C. M. Liedtke, A. C. Nairn, P. Greengard, and M. J. We 1. 1988. Cyclic AMP-dependent protein kinase opens chloride channels in normal but not cystic fibrosis airway epithelium. Nature (Lond.). 331:358-360.

6. Boucher, R. C., M. J. Stutts, M. R. Knowles, L. Cantley, and J. T. Gatzy. 1986. $\mathrm{Na}^{+}$transport in cystic fibrosis respiratory epithelia: abnormal basal rate and response to adenylate cyclase activation. $J$. Clin. Invest. 78:1245-1252.

7. Eliasson, R., B. Mossberg, P. Camner, and B. A. Afzelius. 1977. The immotile-cilia syndrome: a congenial ciliary abnormality as an etiologic factor in chronic airway infections and male sterility. $N$. Engl. J. Med. 297:1-6.

8. Boat, T. F., P. W. Cheng, R. N. Iyer, D. M. Carlson, and I. Polony. 1976. Human respiratory tract secretions: mucous glycoproteins of nonpurulent tracheobronchial secretions, and sputum of patients with bronchitis and cystic fibrosis. Arch. Biochem. Biophys. 177:95-104.

9. Boat, T. F., J. I. Kleinerman, D. M. Carlson, W. H. Maloney, and L. W. Matthews. 1974. Human respiratory tract secretions: mucous glycoproteins secreted by cultured nasal polyp epithelium from subjects with allergic rhinitis and cystic fibrosis. Am. Rev. Respir. Dis. 110:428-441.

10. Frates, R. C., T. Kaizu, and J. A. Last. 1983. Mucous glycoproteins secreted by respiratory epithelial tissue from cystic fibrosis patients. Pediatr. Res. 17:30-34.

11. Chace, K. V., D. S. Leahy, R. Martin, R. Carubelli, M. Flux, and G. P. Sachdev. 1983. Respiratory mucous secretions in patients with cystic fibrosis: relationship between levels of highly sulfated mucin component and severity of the disease. Clin. Chim. Acta. 132:143-155.

12. Yankaskas, J. R., C. U. Cotton, M. R. Knowles, J. I. Gatzy, and R. C. Boucher. 1985. Culture of human nasal epithelial cells on collagen matrix supports: a comparison of bioelectric properties of normal and cystic fibrosis epithelia. Am. Rev. Respir. Dis. 132:1281-1287.

13. Cheng, P. W., R. C. Boucher, J. M. Yankaskas, and T. F. Boat. 1988. Glycoconjugates secreted by cultured human nasal epithelial cells. In Cellular and Molecular Basis of Cystic Fibrosis. G. Mastella and P. M. Quinton, editors. San Francisco Press, Inc., San Francisco, CA. 233-238.

14. Cheng, P. W., J. M. Sherman, T. F. Boat, and P. Bruce. 1981. Quantitation of radiolabelled mucous glycoproteins secreted by tracheal explants. Anal. Biochem. 117:301-306.

15. Bidlingmeyer, B. A., S. A. Cohen, and T. L. Tarvin. 1984. Rapid analysis of amino acids using pre-column derivatization. $J$. Chromatogr. 336:93-104.

16. Knudson, W., M. W. Gandlach, T. M. Schmid, and H. E. Conrad. 1984. Selective hydrolysis of chondroitin sulfates by hyaluronidase. Biochemistry. 23:368-375.

17. Cheng, P. W. 1988. High performance liquid chromotographic analysis of galactosamine, glucosamine, glucosaminitol, and galactosaminitol. Anal. Biochem. 167:265-269.

18. Gibbons, R. A. 1972. Physico-chemical methods for the determination of the purity, molecular size and shape of glycoproteins. In Glycoproteins: Their Composition, Structure and Function. Part A. A. Gottschalk, editor. Elsevier/North Holland, New York. 31-140.

19. Cohn, E. J., and J. T. Edsall. 1943. Proteins, Amino Acids, and Peptides as Dipolar Ions. Reinhold Publishing Corp., New York. 370-381.

20. Elgavish, A., and E. Meezan. 1988. Increased sulfate uptake in skin fibroblasts isolated from cystic fibrosis. Biochem. Biophys. Res. Commun. 152:99-106.

21. Larsen, E. H., and K. Simonson. 1988. Sulfate transport in toad skin: evidence for mitrochondria-rich cell pathways in common with halide ions. Comp. Biochem. Physiol. 90A:709-714.

22. Mulder, G. J. 1981. Sulfate availability in vivo. In Sulfation of Drugs and Related Compounds. G. J. Mulder, editor. CRC Press, Inc., Boca Raton, FL. 31-52.

23. Hirschberg, C. B., and M. D. Snider. 1987. Topography of glycosylation in the rough endoplasmic reticulum and Golgi apparatus. Annu. Rev. Biochem. 56:63-87.

24. Stutts, M. J., M. R. Knowles, J. T. Gatzy, and R. C. Boucher. 1986. Oxygen consumption and ouabain binding sites in cystic fibrosis nasal epithelium. Pediatr. Res. 20:1316-1320.

25. Matthews, L. W., S. Spector, J. Lemm, and J. L. Potter. 1963. Studies of pulmonary secretions from patients with cystic fibrosis, bronchiectasis, and laryngectomy. Am. Rev. Respir. Dis. 88:199-204.

26. Allen, A., M. Mantle, and J. P. Pearson. 1980. The structures and properties of mucus glycoproteins. In Perspectives in Cystic Fibrosis. J. Sturgess, editor. Imperial Press Ltd., Mississauga, Ontario, Canada. 102-112.

27. Mian, N., A. J. Pope, C. E. Anderson, and P. W. Kent. 1982. Factors influencing the viscous properties of chicken tracheal mucins. Biochim. Biophys. Acta. 717:41-48.

28. Krivan, H. C., V. Ginsburg, and D. D. Roberts. 1988. Pseudomonas aeruginosa and Pseudomonas cepacia isolated from cystic fibrosis patients bind specifically to gangliotetraosylceramide and gangliotriaosylceramide. Arch. Biochem. Biophys. 260:493-496.

29. Krivan, H. C., D. D. Roberts, and V. Ginsburg. 1988. Many pulmonary pathogenic bacteria bind specifically to the carbohydrate sequence GalNAc $\beta 1-4 \mathrm{Gal}$ found in some glycolipids. Proc. Natl. Acad. Sci. USA. 85:6157-6161. 